The aggregation and segregation in wild plants at degradation environment at Muradia, Baquba, Iraq

Alhan M. Alwan

\title{
The aggregation and segregation in wild plants at degradation environment at Muradia, Baquba, Iraq
}

\author{
Alhan M. Alwan \\ Biology Department, Science College, University of Diyala, Baquba, Iraq
}

Received: 29 February 2016

Accepted: 2 June 2016

\begin{abstract}
$\underline{\text { Abstract }}$
The study was conducted in October to November 2015 at the neglected and degradation area at the University of Diyala of abandoned spaces, without planting or building between Science and Agriculture Colleges, about $2500 \mathrm{~m}^{2}$. Soil were bulldozed and paved dirt road in its. In this degradation area were found 17 wild plant species belonging to 10 families, (5 species are Poaceae, and 2 species are Fabiaceae). Chosen. 9 species as target plants, because they relatively abundance. The targets plants were: Alhagi graecorium, Capparis spinosa, Cynodon dactylon, Imperata cylindrica, Lycium shawii, Phragmites australis, Prosopis farcta, Shanginia aegyptica, and Sorghum halepanse. Those individuals species plant were taken at central of quadrates for six replicates, in $100 \mathrm{~cm}$ radius, which record all the species within four regions, 25, 50, 75, and $100 \mathrm{~cm}$. The results showed that A. graecorium, C. dactylon, I.cylindrica, $P$ australis, and S. aegyptica were surrounded by about same species (aggregated species). Whereas C. spinosa, P. farcta and L. shawii and S. halepanse surrounded by different species (segregated species), which dependent on abundance values for each one. Sample of soil have been taken under the same plants in six replications. The control soil samples were taken from the spaces between the plants. $\mathrm{pH}$, electrical conductivity (EC), and organic matter (OM) were measured. The results showed that $\mathrm{pH}$ under L. shawii and C. dactylon gave closed value and had significant difference with the rest of species. The electrical conductivity was found to be closed value $C$. spinosa and S. bicolor with each other and the values of low in
\end{abstract}


The aggregation and segregation in wild plants at degradation environment at Muradia, Baquba, Iraq

\section{Alhan M. Alwan}

significant difference with the rest of the target species. Control treatments is significantly different from other in organic matter.

Key words: Aggregation, Seggregation, Alhagi graecorium, Capparis spinosa, Cynodon dactylon, Imperata cylindrica, Lycium shawii, Phragmites australis, Prosopis farcta, Shanginia aegyptica, and Sorghum halepanse.

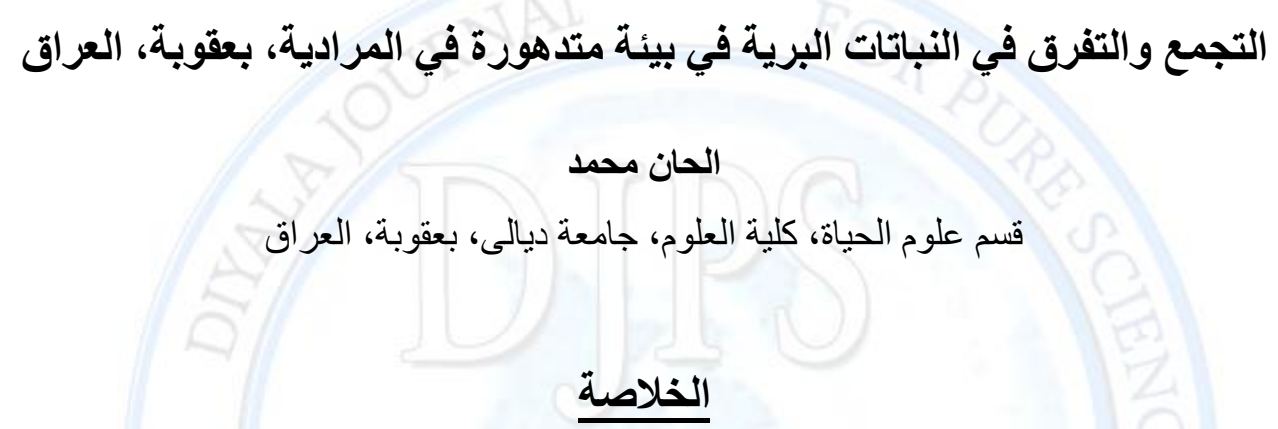

اجريت الدر اسة في محيط جامعة ديالى بين شهري نشرين الأول وتشرين الثاني 2015 في منطقة المر ادية في المساحات

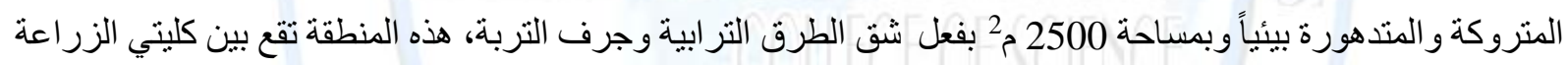
و العلوم. وجد في هذه المنطقة 17 نو عا نباتياً برياً تعود لعشرة عو ائل نباتية، خمسة منها تعود للعائلة النجيلية، و اثثين للعائلة البقولية. أختير ثمانية انو اع منها كنباتات هدف، تم الأختيار بسبب وفرتها نسبياً في المنطقة. هذه الأنواع هي: العاقول، الثفلح،

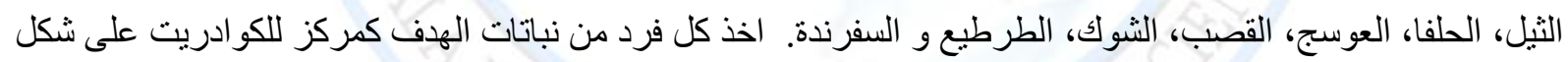
دائرة نصف قطر ها 100 سم وقسمت الى اربع مناطق حول النبات الهدف وهي الى 25، 50، 75 و 100 سم. اظهرت النتائج ان العاقول، الثيل، الحلفا، القصب، السفرندة والطرطيع تتجمع مع بعضها. بينما الثفلح، الثُوك، العوسج و السفرندة تحيط بها نباتات مختلفة (معتمدين في التجمع و التفرق على قيم الغزارة). تم اخذ عينات التربة من تحت النباتات وبعمق 10

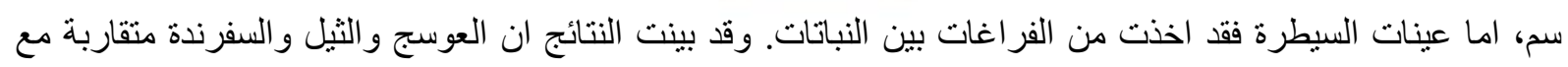
بعضها في الرقم الهيدروجيني ولها فرق معنوي عن بقية نباتات الهدف. اما التوصيل الكهربائي فقد وجد ان الثفلح و السفرندة

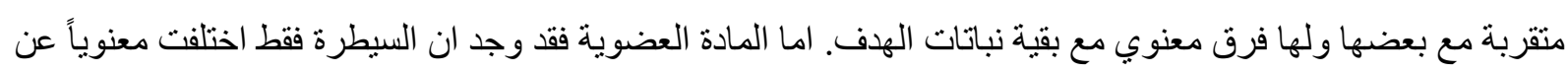
باقي المعاملات.

الكلمات المفتاحية: تجمع النباتات، تفرق التباتات، العاقول، الثفلح، الثيل، الحلفا، العوسج، القصب، الثوك، الطرطيع،

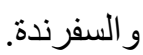


The aggregation and segregation in wild plants at degradation environment at Muradia, Baquba, Iraq

Alhan M. Alwan

\section{Introduction}

Vegetation study in degradation environment region and the survival of some species steadfast in this environment demonstrates the survival of some species steadfast in this environment and reflected the strength of those species as well as the characteristics of those species enable them to live in such degradation environment $[1,2]$. The aim of this study is to highlight the wild plants that remain survive in this degraded region, despite of enormous pressure from drought, pollution, and the action of dirt roads, which the dominance in this region is Shanginia aegyptica [3,4]. Study of aggregation and segregation of the plant species community is of a great importance because it represents a certain plants that combine with each other has been linked, and aggregated with each other by rhizomes $[5,6]$. Some species are falling thier seeds in the same area, do not distribute far away, so that planted nearest together [3]. Others species may have different means of defense and does not need to this gathering or aggregation [7]. The defenses are clearly present in animals and is also present in the plants [8, 2]. The nonclustered or dispersed plants segregation possess other ways as secretion of retardant material inhibited the growth of other species, that may be compete for natural resources as water, nutrients, place or light [9]. The aim of this study is to diagnose the species that can continue to live and grow in the deteriorating and contaminated environment, and to know the accompany species around the target species, is it the same member of species or other species. To conduct those aims were chosen 9 from 17 as target species. The reason of chosen those species because were relatively abundance [10].

\section{Material and Methods}

The study have been carried out in October and November 2015 before the rain fall, and the temperature was 16 to $35 \mathrm{C}^{\circ}$. The location of the area under study is between the faculties of agriculture and science. The area about $2500 \mathrm{~m}^{2}$ where the paved and dirt roads are covered with gravel with coarse sand. The area was neglected since 30 years.

Comprehensive survey was done to record wild plants for the area under study, which the dominant species is Shanginia aegyptica. There are Eucalyptus trees planted long time ago. Eight wild species were selected, named target species from the total 17 wild plants growing 
The aggregation and segregation in wild plants at degradation environment at Muradia, Baquba, Iraq

Alhan M. Alwan

in this region. The circle quadrate was chosen, with radius $100 \mathrm{~cm}$, which were divided into four regions, starting from (target species), as a center of the quadrat, from zero to 25, 50, 75, and $100 \mathrm{~cm}[11,7]$. Those target species were chosen because are relatively abundance. Target species take its as a center of the circles, and the individual plant species were recorded around the target species. The following measurement were recored [12, 13, 14]:

1- density 2-Frequency 3-abundance 4-Dominance, as follows:

1. Density $=$ Number of individual plants per meter $/$ Total of the quadrates, which are 6 replicates.

2. Frequency $=$ Number of times where the individual plant species appear $/$ Number of replicates, then multiplied by 100

3. Abundance $=$ Number of individual plant species $/$ number of quadrate which the individual plant species appeared.

4. Dominance $=$ Frequency plus density .

Soil samples have been taken from the soil under the plant directly in depth of $10 \mathrm{~cm}$ with six replicates. The control samples taken from the spaces between the plants. The measurement $\mathrm{pH}$, Electrical Conductivity (EC) and Organic Matter (OM) were done as described in [15].

\section{$\underline{\text { Results and Discussion }}$}

Result presented in Table 1, Showed there are 17 species of wild plant species in studied area, five of them belong to Poaceae family, two species from each of Fabiaceae, Chenopodaceae and Asteraceae, and some species from Caparaceae, Convolvulaceae, Solanaceae, Brasicaceae, Malvaceae, and Tamaricaceae. Eight species chosen from them as target species, which are: Alhagi graecorium, Capparis spinosa, Cynodon dactylon, Imperata cylindrica, Lycium shawii, Phragmites australis, Prosopis farcta, Shanginia aegyptica, and Sorghum halepanse.

Table 2 showed that the individual species of Alhagi graecorium, surrounded by the same species, which mean aggregate species, the abundance reached $3 \mathrm{~m}^{2}$ at first circle, this value relatively quiet high, as well as existing at the other parts of quadrate, Also we have noted that 
The aggregation and segregation in wild plants at degradation environment at Muradia, Baquba, Iraq

Alhan M. Alwan

dominance this species $68.6,85.1$ at first and second region of quadrate, which regard are quite high values. The connected by rhizomes as defense device, as well as spines, which grazed by herbivore as most of Fabiaceae family plants.

Table 1: Species survey of the area under study.

\begin{tabular}{|c|c|c|c|}
\hline Sequence & Local Name (Arabic) & Scientific Name & Family Name \\
\hline 1 & * عاقول & Alhagi graecorium $*$ & Fabiaceae \\
\hline 2 & شفلح & Capparis spinosa* & Capparaceae \\
\hline 3 & *ثيل & Cynodon dactylon* & Poaceae \\
\hline 4 & مديد & Convolvulus arvensis & Convolvulaceae \\
\hline 5 & حلفا & Imperata cylindrica* & Poaceae \\
\hline 6 & عوسج & Lycium shawii* & Solanaceae \\
\hline 7 & ام الحليب & Lactuca serriola & Asteraceae \\
\hline 8 & جنيبرة & Lipiddium draba & Brasicaceae \\
\hline 9 & خباز & Malva parviflora & Malvaceae \\
\hline 10 & شعير الفأر & Phalaris minor & Poaceae \\
\hline 11 & *صب *قب & Phragmites australis* & Poaceae \\
\hline 12 & شوك & Prosopis farcta* & Fabiaceae \\
\hline 13 & مليح & Sasola kali & Chenopodiaceae \\
\hline 14 & *رطيع & Shanginia aegyptica* & Chenopodiaceae \\
\hline 15 & كلغان & Silybum marianum & Asteraceae \\
\hline 16 & *سفرندة (خريزة) & Sorghum halepanse* & Poaceae \\
\hline 17 & طرفة & Tamarix aucherana & Tamaricaceae \\
\hline
\end{tabular}

Target species*

Table 2: Alhagi graecorium species as a center for a radius $100 \mathrm{Cm}$ around it.

\begin{tabular}{|c|c|c|c|c|c|}
\hline $\begin{array}{l}\text { Distance } \\
(\mathrm{Cm})\end{array}$ & Species & $\begin{array}{l}\text { Density } \\
\text { /m2 }\end{array}$ & Frequency\% & $\begin{array}{c}\text { Abundance } / \mathrm{m} \\
2\end{array}$ & Dominance \\
\hline$\geq 25$ & Alhagi graecorium & 2.0 & 66.6 & 3.0 & 68.6 \\
\hline $26-50$ & $\begin{array}{l}\text { Alhagi graecorium } \\
\text { Prosopis farcta }\end{array}$ & $\begin{array}{l}1.8 \\
0.7\end{array}$ & $\begin{array}{ll}83.3 & 33.3\end{array}$ & 2.0 & $85.1 \quad 34.0$ \\
\hline $51-75$ & Alhagi graecorium & 0.3 & 16.6 & 2.0 & 16.9 \\
\hline $76-100$ & Alhagi graecorium & 1.0 & 50.0 & 2.0 & 51.0 \\
\hline
\end{tabular}

Table 3 showed that Capparis spinosa, surrounded by different plant species, included Shanginia aegeptica and Imperata cylindrica. This target species doesn't appear as high aggregate, we could name as semi aggregate, may be because herbivore did not palatable it for 
The aggregation and segregation in wild plants at degradation environment at Muradia, Baquba, Iraq

Alhan M. Alwan

grazing it, so will not need such aggregate device, [7]. It is also depends on itself to get on the water by extended its root deeply in the soil [3]. Associated by I. cylindrica, S. aegyptica and A. graecorium.

Table 3: Survey of Capparis spinosa species as a central of quadrate for a radius $\mathbf{1 0 0}$ Cm.

\begin{tabular}{|c|l|c|c|c|c|}
\hline $\begin{array}{c}\text { Distance } \\
(\mathrm{cm})\end{array}$ & \multicolumn{1}{|c|}{ Species } & $\begin{array}{c}\text { Density/m } \\
2\end{array}$ & Frequency\% & Abundance $/ \mathrm{m}^{2}$ & Dominance \\
\hline$\geq 25$ & Capparis spinosa & 1.3 & 16.6 & 2.0 & 17.9 \\
& Imperata cylindrica & 0.3 & 16.6 & 2.0 & 16.9 \\
& Alhagi graecorium & 0.2 & 16.6 & 1.0 & 16.8 \\
& Shanginia aegyptica & 0.5 & 16.6 & 3.0 & 17.1 \\
& Convolvulus arvensis & 0.2 & 16.6 & 1.0 & 16.8 \\
\hline $26-50$ & Capparis spinosa & 0.4 & 16.6 & 2.0 & 17.0 \\
& Imperata cylindrica & 0.6 & 16.6 & 4.0 & 17.2 \\
& Alhagi graecorium & 0.2 & 16.6 & 1.0 & 16.8 \\
& Sorghum halepanse & 0.2 & 16.6 & 1.0 & 16.8 \\
& & & & & 16.8 \\
\hline $51-75$ & Imperata cylindrica & 0.2 & 16.6 & 2.0 & 16.9 \\
& Alhagi graecorium & 0.3 & 16.6 & 3.0 & 17.1 \\
\hline $76-100$ & Shanginia aegyptica & 0.5 & 16.6 & 1.0 & 16.8 \\
& Capparis spinosa & 0.2 & 16.6 & 1.0 & 16.8 \\
& Shanginia aegyptica & 0.2 & 16.6 & 1.0 & 16.8 \\
\hline
\end{tabular}

Table 4 represent wild Cynodon dactylon, which noted that most of individual species surrounded are the same individual species, as the aggregation pointed out the aggregation which reached $4.3 / \mathrm{m}^{2}$ at the first part of quadrate, which regarded high value. That is mean aggregation with each other which individual plant connected together by rhizomes [10]. We noted also the Dominance reached, 104.3, 84.9, 85.5 68.2 for the 4 parts of quadrate respectively some individual species of I. cylindrica and S. aegyptica. 
The aggregation and segregation in wild plants at degradation environment at Muradia, Baquba, Iraq

Alhan M. Alwan

Table 4: Cynodon dactylon species as a central of quadrate for a radius $100 \mathrm{Cm}$ around it.

\begin{tabular}{|c|c|c|c|c|c|}
\hline $\begin{array}{l}\text { Distance } \\
(\mathrm{Cm})\end{array}$ & Species & Density $/ \mathrm{m}^{2}$ & Frequency $\%$ & Abundance $/ \mathrm{m}^{2}$ & Dominance \\
\hline$\geq 25$ & $\begin{array}{l}\text { Cynodon dactylon } \\
\text { Imperata cylindrica } \\
\text { Alhagi graecorium }\end{array}$ & $4.3 \quad{ }^{0.2}$ & $\begin{array}{l}100 \\
16.6 \\
16.6\end{array}$ & $\begin{array}{l}4.3 \\
1.0 \\
1.0\end{array}$ & $\begin{array}{c}104.3 \\
16.8 \\
16.8\end{array}$ \\
\hline $26-50$ & $\begin{array}{l}\text { Cynodon dactylon } \\
\text { Imperata cylindrica } \\
\text { Shanginia aegyptica }\end{array}$ & $1.6 \quad 0.2$ & $\begin{array}{l}83.3 \\
16.6 \\
66.6\end{array}$ & $\begin{array}{l}2.0 \\
1.0 \\
1.0\end{array}$ & $\begin{array}{l}84.9 \\
16.8 \\
67.4\end{array}$ \\
\hline $51-75$ & $\begin{array}{l}\text { Cynodon dactylon } \\
\text { Imperata cylindrica } \\
\text { Shanginia aegyptica }\end{array}$ & $\begin{array}{lll}2,2 & & 0.5 \\
& 0.5 & \end{array}$ & $\begin{array}{l}83.3 \\
16.6 \\
50.0\end{array}$ & $\begin{array}{l}2.6 \\
2.0 \\
1.0\end{array}$ & $\begin{array}{l}85.5 \\
17.1 \\
50.5\end{array}$ \\
\hline $76-100$ & $\begin{array}{l}\text { Cynodon dactylon } \\
\text { Alhgi graecorium }\end{array}$ & 2.2 & $\begin{array}{l}66.6 \\
16.6\end{array}$ & $\begin{array}{l}3.3 \\
1.0\end{array}$ & $\begin{array}{l}68.2 \\
16.8\end{array}$ \\
\hline
\end{tabular}

Table 5 represent Imperrata cylindrica, which noted most of the individual plants are the same species, which the abundance reached fairy high $5 / \mathrm{m}^{2}$ for abundance, and 104.6 for dominance, which regards are quite highest values. Its mean this species is aggregate by rhizomes, also [3] noted Shanginia aegeptica, which this species is a dominant in this area under study, in other hand the two parts of qudrate, 75 , and $100 \mathrm{~cm}$ were empty from any plant

Table 5: Imperat cylindrica species as a central of quadrate for a radius $100 \mathrm{Cm}$.

\begin{tabular}{|c|l|c|c|c|c|}
\hline $\begin{array}{c}\text { Distance } \\
(\mathrm{Cm})\end{array}$ & \multicolumn{1}{|c|}{ Species } & $\begin{array}{c}\text { Density } \\
/ \mathrm{m}^{2}\end{array}$ & Frequency\% & Abundance $/ \mathrm{m}^{2}$ & Dominance \\
\hline$\geq 25$ & Imperata cylindrica & 4.6 & 100 & 5.0 & 104.6 \\
& Prosopis farcta & 0.1 & 16.6 & 1.0 & 16.7 \\
& Shanginia aegyptica & 0.3 & 33.3 & 2.0 & 33.6 \\
& Cynodon dactylon & 0.5 & 50.0 & 3.0 & 50.5 \\
\hline $26-50$ & Imperata cylindrica & 2.3 & 4.0 & 4.0 & 6.3 \\
& Shanginia aegyptica & 0.3 & 100 & 1.0 & 100.3 \\
& Convolvulus arvensis & 0.5 & 33.3 & 1.0 & 33.8 \\
& Cynodon dactylon & & & & 1.0 \\
\hline $51-75$ & --------- & 0.1 & 16.6 & -1.0 & 16.7 \\
\hline $76-100$ & ------------- & ----- \\
\hline
\end{tabular}


The aggregation and segregation in wild plants at degradation environment at Muradia, Baquba, Iraq

\section{Alhan M. Alwan}

Table 6 represent, Lycium shawii, which noted this plant semi- aggregated with its self, but doesn't intensity for each part of the quadrates, the dominance is relatively high value at second and third part of quadrate (67.3 and 50.6 respectively). The reason for that might be because this species relatively large size. Associated with this species, such as C. dactylon, and S. halepanse. Those two species the are very little competition with L. shawii because L.shawii has tap root go deep in the soil, whereas C.dactylon and S. halepanse have fibrous roots, which distributed near the surface of soil [16].

Table 6: Lycium shawii species as a central of quadrate for a radius $100 \mathrm{Cm}$.

\begin{tabular}{|c|l|c|c|c|c|}
\hline $\begin{array}{c}\text { Distance } \\
(\mathrm{cm})\end{array}$ & \multicolumn{1}{|c|}{ Species } & Density $/ \mathrm{m}^{2}$ & $\begin{array}{c}\text { Frequency } \\
\%\end{array}$ & Abundance $/ \mathrm{m}^{2}$ & Dominance \\
\hline$\geq 25$ & Lycium shawii & 1.3 & 33.3 & 1.0 & 34.6 \\
& Cynodon dactylon & 0.3 & 33.3 & 1.0 & 33.6 \\
\hline \multirow{2}{*}{$6-50$} & Lycium shawii & 0.6 & 66.7 & 1.0 & 67.3 \\
& Sorghum halepanse & 0,3 & 16.6 & 2.0 & 16.9 \\
& Cynodon dactylon & 0.3 & 33.3 & 1.0 & 33.6 \\
\hline \multirow{2}{*}{$51-75$} & Lycium shawii & 0.6 & 50.0 & 1.3 & 50.6 \\
& Sorghum halepanse & 0.1 & 16.6 & 1.0 & 16.7 \\
& Shanginia aegyptica & 0.1 & 16.6 & 1.0 & 16.7 \\
\hline $76-100$ & Lycium shawii & 0.1 & 16.6 & 1.0 & 16.7 \\
& Prosopis farcta & 0.1 & 16.6 & 1.0 & 16.7 \\
& Capparis spinosa & 0.1 & 16.6 & 1.0 & 16.7 \\
\hline
\end{tabular}

Table 7 represent Phragmites australis, surrounde by the same species, which the abundance recorded quite high, its reached $5,5 / \mathrm{m}^{2}$, its mean aggregate with individual of same individual species, which the abundance reached fairy high $5.5 / \mathrm{m}^{2}$ and the dominance was 101.8 . This species possess rhizome connected with each other, also found some of other species lived with them, such I. cylindrica, C. dactylon and S. aegyptica. 
The aggregation and segregation in wild plants at degradation environment at Muradia, Baquba, Iraq

Alhan M. Alwan

Table 7: Phragmites australis species as a central of quadrate for a radius $100 \mathrm{Cm}$.

\begin{tabular}{|c|l|c|c|c|c|}
\hline $\begin{array}{c}\text { Distance } \\
\left(\mathrm{Cm}^{2}\right)\end{array}$ & \multicolumn{1}{|c|}{ Species } & $\begin{array}{c}\text { Density/ } \\
\mathrm{m}^{2}\end{array}$ & Frequency\% & Abundance $/ \mathrm{m}^{2}$ & Dominance \\
\hline$\geq 25$ & Phragmites australis & 1.8 & 100 & 5.5 & 101.8 \\
& Prosopis farcta & 0.1 & 16.6 & 1.0 & 16.7 \\
& Cynodon dactylon & 0.3 & 33.3 & 1.0 & 33.6 \\
& Imperata cylindrica & 0.1 & 16.6 & 1.0 & 16.7 \\
\hline $26-50$ & Phragmites australis & 0.8 & 33.0 & 2.5 & 33.8 \\
& Cynodon dactylon & 0.2 & 16.6 & 1.0 & 16.8 \\
& Imperata cylindrica & 0.2 & 16.6 & 3.0 & 16.8 \\
\hline $51-75$ & Phragmites australis & 0.2 & 16.6 & 1.0 & 16.8 \\
& Imperata cylindrica & 1.6 & 83.3 & 2.0 & 84.9 \\
& Shanginia aegyptica & 0.2 & 16.6 & 1.0 & 16.8 \\
\hline $76-100$ & Cynodon dactylon & 0.5 & 33.3 & 1.5 & 33.8 \\
& Imperata cylindrica & 1.0 & 33.3 & 3.0 & 34.3 \\
\hline
\end{tabular}

Table 8 represent prosopis faracta, which surrounded by different species which do not aggregate, in spite of Dominance 84 in the first part of quadrate, but the abundance at the same part was relatively low value (1.2). which is the abundance about similar with other species, its mean (segregation) with its individual. It is well known that this species possess very deep roots, may be reach to $30 \mathrm{~m}$ deep in the earth to reach ground water. So will not need to aggregate with each other for surviving and associated with A. graecorium, $C$. dactylon, and L. shawii.

Table 8: Prosopis faracta species as a central of quadrate for a radius $100 \mathrm{Cm}$.

\begin{tabular}{|c|l|c|c|c|c|}
\hline $\begin{array}{c}\text { Distance } \\
\left(\mathrm{cm}^{2)}\right)\end{array}$ & \multicolumn{1}{|c|}{ Species } & Density $/ \mathrm{m}^{2}$ & Frequency \% & Abundance $/ \mathrm{m}^{2}$ & Dominance \\
\hline$\geq 25$ & Prosopis farcta & 1.0 & 83.0 & 1.2 & 84.0 \\
& Alhagi graecorium & 0.2 & 16.0 & 1.0 & 16.2 \\
\hline $26-50$ & Prosopis farcta & 0.8 & 20.0 & 1.6 & 20.8 \\
& Alhagi graecorium & 0.3 & 16.6 & 2.0 & 16.9 \\
& Sorghum halepans & 0.3 & 16.6 & 2.0 & 16.9 \\
& Cynodon dactylon & 0.1 & 16.6 & 1.0 & 16.7 \\
& Shanginia aegyptica & 0.5 & 33.3 & 1.5 & 33.8 \\
\hline $51-75$ & Lycium shawii & 0.1 & 16.6 & 1.0 & 16.7 \\
& Prosopis farcta & 0.1 & 16.6 & 1.0 & 33.6 \\
\hline $76-100$ & Shanginia aegyptica & 0.3 & 33.3 & 1.0 & 16.7 \\
& Lycium shawii & 0.1 & 16.6 & 1.0 & 33.6 \\
\hline
\end{tabular}


The aggregation and segregation in wild plants at degradation environment at Muradia, Baquba, Iraq

Alhan M. Alwan

Table 9 represent Shanginia aegeptica, its aggregated with each other, which the abundance reach $6 / \mathrm{m}^{2}$ at the second region of quadrate, and 102 for dominance value. Growing with this species: C. spinosa and P. farcta.

Table 9: Shanginia aegyptica species as a central of quadrate for a radius $100 \mathrm{Cm}$.

\begin{tabular}{|c|l|c|c|c|c|}
\hline $\begin{array}{c}\text { Distance } \\
\left(\mathrm{Cm}^{2)}\right)\end{array}$ & \multicolumn{1}{|c|}{ Species } & $\begin{array}{c}\text { Density/ } \\
\mathrm{m}^{2}\end{array}$ & $\begin{array}{c}\text { Frequency } \\
\%\end{array}$ & Abundance $/ \mathrm{m}^{2}$ & Dominance \\
\hline$\geq 25$ & Shanginia aegyptica & 0.5 & 50.0 & 1.0 & 50.5 \\
& Capparis spinosa & 0.1 & 16.6 & 1.0 & 16.7 \\
\hline $26-50$ & Shanginia aegyptica & 2.0 & 100 & 6.0 & 102.0 \\
& Prosopis farcta & 0.1 & 16.6 & 1.0 & 16.7 \\
& Capparis spinosa & 0.1 & 16.6 & 1.0 & 16.7 \\
\hline $51-75$ & Shanginia aegyptica & 0.3 & 33.3 & 1.0 & 33.6 \\
& Prosopis farcta & 0.1 & 16.6 & 1.0 & 16.7 \\
\hline $76-100$ & Shanginia aegyptica & 0.6 & 16.6 & 1.0 & 17.2 \\
\hline
\end{tabular}

Table 10 represent Sorghum halepanse, which surrounded by the about same species, which abundance reached $3 / \mathrm{m}^{2}$ and 103 for dominance, this means is aggregate, but also associated with its C. dactylon, I. cylindrica and C. spinosa.

Table 10: Survey of Sorghum halepanse as a central of quadrate for a radius $100 \mathrm{Cm}$.

\begin{tabular}{|c|l|c|c|c|c|}
\hline $\begin{array}{c}\text { Distanc } \\
\mathrm{e}\left(\mathrm{Cm}^{2)}\right)\end{array}$ & \multicolumn{1}{|c|}{ Species } & Density/m & Frequency \% & Abundance $/ \mathrm{m}^{2}$ & Dominance \\
\hline$\geq 25$ & Sorghum halepanse & 3.0 & 100 & 3.0 & 103.0 \\
& Cynodon dactylon & 0.3 & 33.3 & 1.0 & 33.6 \\
& Imperata cylindrica & 0.1 & 16.6 & 1.0 & 16.7 \\
\hline \multirow{2}{*}{$6-50$} & Sorghum halepanse & 0.8 & 66.6 & 1.1 & 67.4 \\
& Cynodon dactylon & 0.5 & 33.3 & 1.5 & 33.8 \\
& Cynodon dactylon & 0.5 & 16.6 & 1.5 & 17.1 \\
\hline $51-75$ & ------------ & ------ & ------ & ------- & ------- \\
\hline $76-100$ & Capparis spinosa & 0.1 & 16.6 & 1.0 & 16.7 \\
\hline
\end{tabular}

From the above Tables, we could divided the target specie into two groups. First are aggregated species, such as A. graecorium, C. dactylon, I.cylindrica, P australis, and S. aegyptica, and S. halepanse, Whereas the second group are semi-segregated or weak aggregated, species, represented by $C$. spinosa, Only $P$. fracta represent segregation species. Most of aggregation plant species have rhizome connected individual which each other; this is help to defense and to help each other for getting natural resources, [3] Table 11 showed the values of $\mathrm{pH}$, EC, and $\mathrm{OM}$ for the soil under target species growing on its. For the $\mathrm{pH}$ there are significant difference 
The aggregation and segregation in wild plants at degradation environment at Muradia, Baquba, Iraq

\section{Alhan M. Alwan}

between group of species, C. dactylon, L. shawii and S. halepanse, which gave higher value than the rest of the target species including the control. The Electrical Conductivity (EC), which represent the amount of salts in the soil, which noted that $C$. spinosa and S. aegeptica as group different significantly with higher value than the other target species, and tolerant the soil salinity which those two species tolerated soil salinity [17]. Whereas organic matter (OM) showed that is only control significantly difference from all the target species, this is of course because no any leaves or remain of plants at the space of the vegetation.

Table 11: Soil characteristics of target species which have been taken from root system for each target species. (Difference, A, B letters represent significant different at $\mathbf{p} \leq \mathbf{0 . 0 5})$.

\begin{tabular}{|l|c|c|c|}
\hline \multicolumn{1}{|c|}{ Species } & $\mathrm{pH}$ & $\mathrm{EC}$ & OM \\
\hline Alhagi graecorium & $7.38 \mathrm{ab}$ & $1.55 \mathrm{ab}$ & $0.49 \mathrm{a}$ \\
\hline Copparis spinosa & $7.41 \mathrm{a}$ & $2.53 \mathrm{~b}$ & $0.48 \mathrm{a}$ \\
\hline Cynodon dactylon & $7.48 \mathrm{~b}$ & $1,15 \mathrm{a}$ & $0.47 \mathrm{a}$ \\
\hline Imperata cylindrica & $7.28 \mathrm{a}$ & $1.94 \mathrm{a}$ & $0.46 \mathrm{a}$ \\
\hline Lycium shawii & $7.49 \mathrm{~b}$ & $1.96 \mathrm{a}$ & $0.48 \mathrm{a}$ \\
\hline Phragmites australis & $7.31 \mathrm{a}$ & $1.95 \mathrm{a}$ & $0.48 \mathrm{a}$ \\
\hline Prosopis fracta & $7.28 \mathrm{a}$ & $1.55 \mathrm{a}$ & $0.47 \mathrm{a}$ \\
\hline Shanginia aegyptica & $7.30 \mathrm{a}$ & $3.55 \mathrm{~b}$ & $0.45 \mathrm{a}$ \\
\hline Sorghum halepanse & $7.53 \mathrm{~b}$ & $1.92 \mathrm{a}$ & $0.47 \mathrm{a}$ \\
\hline Control & $7.39 \mathrm{ab}$ & $2.35 \mathrm{a}$ & $0.44 \mathrm{~b}$ \\
\hline
\end{tabular}

$a, b$ letters represent significant different 
The aggregation and segregation in wild plants at degradation environment at Muradia, Baquba, Iraq

Alhan M. Alwan

\section{$\underline{\text { References }}$}

1. Mahdi, A. S. and Al-Khulaidi, A. A. (1999). Vegetation study of Degradationmountain at Taiz, Yemen. J. Diala, 1(6): 75-93.

2. Schneider, A.; Law, R.; and Illian, J. B. (2006). Quantitative of neiborhood-dependent plant growth by Bayesian Hierachical Modeling. J. Ecology, 94: 310-321.

3. Grime, J. P. (1990). Plant strategies and vegetation process. John Wiley \& sons, Chichester, UK.

4. Hotsky, B. L.; Kovacs, B.; Onodi, G. (2016). Effect of plant function group loss on soil biota and net ecosystem exchange: a plant removal experiment in Mongolian grassland. J. Ecology, 104(1): 145-156.

5. Ackerly, D. D. (2004). Adaptation niche conservation and convergence of leaf evaluation in the California Chaparral, American Naturalist, 163, 654-671.

6. Voorde, T. F.; Putten, W. F. and Bezemer, T. M. (2011). Intra and interspespeific plantsoil interactions, soil legacies and priority. J. Ecology, 99: 945-953.

7. Law, R.; Illian, J.; Buslem, D.; Gratzer. G. and Gunatilleke, C. (2009). Ecological information from spatial patterns of plant insights from point process theory. J. Ecology, 97: 616-628.

8. Begon, M.; Harper, J. L. and Townsend, C. R. (1990). Ecological individuals, population and communities. Blackwell Scientific Publication, London, UK.

9. Chen, D.; Pan, Q.; Bai, Y; Hu, S.; Huang, J. and Wang, Q. (2016). Chenges in assembly rules along a stress gradient from open dry grassland to wetlands. J. of Ecology 104(2): 507-517.

10. Bolker, B. M.; Pacala, S. W. and Neuhauser, C. (2003). Spatial dynamics in model plant communities: What do we really know? American Naturalist, 162: 135-148.

11. Mahdi, A. S. (1988). The plant Ecology of a limestone grassland community: spatial organization and coexistence. $\mathrm{PhD}$ Thesis, University of Sheffield, UK.

12. Rump, H. H. and Krist, H. (1994). Laboratory Manual for the examination of water, west water and soil, VCH, Germany. 
The aggregation and segregation in wild plants at degradation environment at Muradia, Baquba, Iraq

\section{Alhan M. Alwan}

13. Keshaw, K. A. and Looney, J. H. (1995). Quantitative dynamic pant ecology. Edward Arnold, Scotland, UK.

14. Greiog-Smith, P. (1998). Quantitative plant ecology. Blackwell Scientific Publications, Oxford, UK.

15. Allen, E, B.; Grimshow, H. H.; Parkinson, J. A, and Quarmby, C. (1974). Chemical analysis of ecological materials. Blackwell Scientific Publications, Oxford, UK.

16. Gross, N.; Slavorel, N. and Croumet, S. L. (2007). Complementary as mechanism of coexistence between functional group grasses. J. Ecology, 95: 1296-1305.

17. Sheltot, H. (2004). Plant Ecology. Enn-Smes University Press, Cairo, Egept. 